\title{
Psychological treatments of trauma consequences in mental health
}

\author{
Ioanna Giannopoulou \\ From $1^{\text {st }}$ International Congress on Neurobiology and Clinical Psychopharmacology and European \\ Psychiatric Association Conference on Treatment Guidance \\ Thessaloniki, Greece. 19-22 November 2009
}

\section{Introduction}

Survivors of different trauma events may present with different severity and length of symptoms. Various theoretical paradigms have been applied to understanding post-traumatic reactions but each model has its advantages and limitations to the extent it explains the posttrauma phenomenology.

\section{Aim}

This presentation will focus on the integrative model of adjustment following trauma events (i.e. stimulus, appraisal, emotional state, personality, socio-cultural factors and coping strategies) and its implication for clinical practice, with particular reference to various methods of psychological treatment, planning and implementing psychosocial interventions.

\section{Conclusions}

Psychological treatments based on CBT models are an integral part of delivering effective therapeutic interventions.

Submit your next manuscript to BioMed Central and take full advantage of:

- Convenient online submission

- Thorough peer review

- No space constraints or color figure charges

- Immediate publication on acceptance

- Inclusion in PubMed, CAS, Scopus and Google Scholar

- Research which is freely available for redistribution 